ISSN 2338-5324 (print)

ISSN 2442-7276 (online)

Online di http://jkp.fkep.unpad.ac.id

DOI : $10.24198 / \mathrm{jkp}$

\title{
Quality of Nurse Work Life in Pangandaran Health Center
}

\author{
Irman Somantri, Kurniawan Yudianto \\ Faculty of Nursing, Universitas Padjadjaran \\ Email:Irman.somantri@unpad.ac.id
}

Submitted: 04-12-2017 Accepted: 25-12-2018 Published: 31-12-2018

\begin{abstract}
Quality service is the main goal of the health care system, where the purpose of service quality is to ensure that the services or products of nursing services are produced according to the patient's standards/ desires. The purpose of this study was to find out the quality of work life of nurses in the Puskesmas. This study uses correlative design that connects the characteristics with the quality of the work life of nurses. The research sample was 48 nurses in Puskesmas who were taken by total sampling. Comparative test was carried out using Mann Whitney, Kruskall Wallis, and Spearman tests adjusted for the type of data The results are displayed in the form of numerical data tables consisting of middle values, deviations and probability values. The total quality of work life of nurses in Pangandaran Health Center was 145.83 where the value obtained was below the average standard value of 150. Likewise for the aspect of work environment, relations with managers, work conditions and job perceptions which had a mean below the standard mean while the support service aspect has an average of 19.31 while the average standard is 18 . Based on the comparative analysis, gender and age have no relationship with the quality of work life ( $p$ value $>0.005$ ), while the level of education, the number of teams and salaries have a relationship with quality working life of nurses in Pangandaran Health Center ( $p$ value $<0.001$ ). This means that nurses have not felt well in their work, except in the aspect of support service in this aspect nurses have felt satisfied and prosperous in getting support from other teams/officers. Likewise, the level of education, the number of teams and salaries have an influence on the quality of the worker's life.
\end{abstract}

Keywords: QNWL, quality of nursing work life. 
Irman Somantri : Quality of Nurse Work Life In Pangandaran Health Center

\section{Introduction}

Quality service is the main goal of the health care system, where the purpose of service quality is to ensure that the services or products of nursing services are produced according to the patient's standards/desires. Patients as recipients of care become a benchmark of the success of the services provided, whether it is in accordance with the quality expected by the patient, or not (Nursalam, 2012).

The uniqueness of service users has implications for the services provided. Care activities are one of the core of hospital services. As the spearhead of service, the demand for quality service (service of excellent) becomes a necessity. The implementation of care is a humanitarian activity, but with a professional approach, because it is based on a standardized plan and procedure (Kotler \& Keller, 2012).

Law No. 38 of 2014 states that Nursing Services is a form of professional service which is an integral part of health services based on nursing knowledge and tips aimed at individuals, families, groups, or communities, both healthy and sick (State Gazette of the Republic of Indonesia, 2014), with this the nursing service becomes very important in a health service in a health agency.

The Community Health Center (Puskesmas) is a health service facility that organizes public health efforts and first-rate individual health efforts, by prioritizing promotive and preventive efforts, to achieve the highest level of public health in its working area (State Gazette of the Republic of Indonesia, 2014) .

Improving the quality of service is very necessary to be able to ensure accountability of Puskesmas services, therefore to support this, each Puskesmas needs to be assessed in the form of accreditation. In accordance with the Regulation of the Minister of Health of the Republic of Indonesia Number 75 of 2014 in Article 1 paragraph 8 states that Puskesmas accreditation is an acknowledgment of the Puskesmas provided by an independent accreditation organizing institution established by the Minister after being assessed that the Puskesmas has met the Puskesmas service standards set by the Minister to improve quality of service for
Puskesmas on an ongoing basis (State Gazette of the Republic of Indonesia, 2014).

The accreditation process is designed to improve the culture of safety and culture of quality in health service agencies, so that it always strives to improve the quality and safety of its services (Director General of Health Ministry of Health Republic of Indonesia and KARS, 2011).

One of the effects of district development and with a determined vision, especially to achieve security and comfort in one of the activities carried out by the Pangandaran district government is to try to improve the community health status in its territory. At present the health index of Pangandaran population is at 76.68 higher than the health index of West Java Province which is 74.01 (Health Index, 2015).

Pangandaran Public Health Center accepts patients who need hospitalization, even though there is very little energy, where there are only 2 nurses on duty at night and day with a large number of patients.

Based on this explanation, the researchers considered it important to examine the service quality of Pangandaran Health Center, especially in the aspect of quality of work life of nurses as a reference for Puskesmas which would later develop into hospitals.

Quality of work life is not a single job design, but rather focuses on all aspects of the work climate or work culture (Luthans, 2011). Quality of work life is a system that includes ways to improve the quality of life by creating better jobs (Nawawi, 2001). In nursing management, the concept of quality of work life (QWL) is known as quality of nursing work life. Quality of nursing working life is a perception or assessment of nurses regarding all dimensions that affect the quality of work life that is related to their experience in working in order to achieve organizational goals (Luthans, 2011).

Based on some of the above understanding, it can be concluded that the quality of work life is the perception of the worker in this case the nurse to the system so that it will affect the work climate and work culture

Factors that influence quality of nursing work life (QNWL), which are influenced by organizational characteristics, the nature of nursing work, appreciation of values, human 
Irman Somantri : Quality of Nurse Work Life In Pangandaran Health Center

resources, collective relationships, and career development (Sirin \& Sokmen, 2015).

The dimensions of the quality of work life of the nurse were further developed into 5 factors (Sirin \& Sokmen, 2015), namely:

1.Work Environment, which contains opinions from the public about the nursing profession, communication with other health teams, assistance in improving competencies through continuing training and education, action policies and procedures in nursing, security in work and respect from leaders towards nursing.

2. Relation with Managers which contains nurses' perceptions of communication with leaders, supervision activities, feedback and appreciation from supervisors to their employees.

3. Work Conditions, which contain perceptions of the severity of work, the balance between work and family and work time.

4. Job Perception which contains autonomy in carrying out work activities, acceptance from other teams and the mechanism at work. 5. Support Service which contains assistance that can be obtained other than from the health team, available infrastructure.

\section{Method}

This research is a quantitative research with analysis using descriptive and correlative to relate the characteristics of nurses to the quality of their work life. Samples from this study were all nurses at Pangandaran Health Center.

Nurse's Quality of Work Life Quality Instrument uses the Brooks' Quality of Nursing Work Life Questionnaire instrument Quality of Work Life in the form of a

Table 1 Characteristic of Respondents

\begin{tabular}{|c|c|c|c|}
\hline \multicolumn{2}{|c|}{ Variable } & \multirow{2}{*}{$\begin{array}{c}\text { Frequency } \\
31\end{array}$} & \multirow{2}{*}{$\begin{array}{c}\text { Percentage } \\
64.6\end{array}$} \\
\hline Gender & Male & & \\
\hline & Female & 17 & 35.4 \\
\hline \multirow[t]{4}{*}{ Education of Nurse } & Diploma III & 16 & 33.3 \\
\hline & Strata 1 & 11 & 22.9 \\
\hline & Ners & 11 & 22.9 \\
\hline & Non Ners & 10 & 20.8 \\
\hline \multirow[t]{2}{*}{ Teammate } & 4 peoples & 26 & 54.2 \\
\hline & 5 peoples & 22 & 45.8 \\
\hline
\end{tabular}

modified Likert scale construction based on variables into 5 subvariables consisting of: Work Environment, Relations with Manager, Work Conditions, Job Perceptions, and Support Service (Sirin \& Sokmen, 2015) and for the question items were developed by the researcher so that there were 50 question items using a Likert scale in the 1-5 range.

The quality of work life data was analyzed using descriptive analysis using middle values (mean, median) and deviation values (standard deviation, range of values) for the variable quality of work life.

The analysis of the relationship between individual characteristics and the dependent variable (quality of work life) was carried out in a comparative test, with mann whitney test, wallis and spearman kallkall adjusted to the type of data.

To ensure that this research is of high quality, the researchers used several ethical principles of research including respondents not including personal identities (personal identities were only written by researchers on separate sheets) and guaranteed confidentiality of data from respondents. To see the willingness of the respondent beforehand the respondent was given an explanation of the purpose and benefits of the study, where in this study all respondents were willing to become research respondents marked by signing the informed consent sheet provided by the researcher.

\section{Result}

The results of the study for the demographic data of respondents can be seen in Table 1 below. 
Irman Somantri : Quality of Nurse Work Life In Pangandaran Health Center

\begin{tabular}{lccc} 
Take home pay & $<2,500,000$ & 20 & 41.7 \\
& $>2,500,000$ & 28 & 58.3 \\
Age (year) & Mean & 31.22 & \\
& Minimun-maximum & $21-50$ & \\
\hline
\end{tabular}

Table 2 Quality of Nursing Worklife

\begin{tabular}{lcccc}
\hline \multicolumn{1}{c}{ Variable } & Average & Mean & Standar Deviation & Rentang Skor \\
\hline 42 Item-Scale & 150 & 145.83 & 60.46 & $63-202$ \\
$\begin{array}{l}\text { - Work Environment (12 } \\
\text { items) }\end{array}$ & 36 & 35.29 & 14.94 & $15-51$ \\
- Relation with Managers (5 & 15 & 14.50 & 6.73 & $5-21$ \\
items) & & & & \\
- Work Conditions (12 items) & 36 & 33.94 & 13.96 & $16-48$ \\
- Job Perception (15 items) & 45 & 42.88 & 19.32 & $17-60$ \\
- Support Service (6 items) & 18 & 19.31 & 6 & $9-27$ \\
\hline
\end{tabular}

Tabel 3 The Relationship between the Characteristics of Officers and the Quality of Work Life

\begin{tabular}{lccccc}
\hline \multicolumn{1}{c}{ Variable } & Frequency & Mean & Min-Max & $\begin{array}{c}\text { Standar } \\
\text { Deviation }\end{array}$ & p value \\
\hline Gender & 31 & 145.67 & $63-202$ & 59.8 & $0.720^{1}$ \\
Male & 17 & 146.11 & $63-200$ & 63.49 & \\
Female & & & & & \\
Level of Education & 16 & 132 & $64-202$ & 61.31 & $<0.001^{2}$ \\
Diploma 3 & 11 & 183.72 & $64-200$ & 39.86 & \\
Strata 1 & 11 & 201.2 & $154-200$ & 13.07 & \\
Ners & 10 & 91.63 & $63-122$ & 23.25 & \\
Non Ners & & & & & \\
Jumlah Tim & 26 & 188.04 & $63-202$ & 30.12 & $<0.001^{1}$ \\
4 peoples & 22 & 95.95 & $63-200$ & 47.8 & \\
5 peoples & & & & & \\
Gaji/penghasilan & 20 & 79.4 & $63-154$ & 28.35 & $<0.001^{1}$ \\
$<2,500,000$ & 28 & 198.67 & $125-202$ & 13.89 & \\
$>$ 2,500,000 & 48 & 31.23 & $21-50$ & 5.34 & $0.206^{3}$ \\
Age & & & & & \\
\hline
\end{tabular}

Table 1 shows that most of the respondents in this study were men $(64.6 \%)$ with the majority being nursing teams with nursing diploma III education (33.3\%), with 5 team members $(45.8 \%)$ and most have income (salary) per month above 2.5 million rupiah $(58.3 \%)$ and the average age of officers and nurses in Pangandaran Health Center is at the age of 31.22 years which means being in early adulthood and is a productive age.

Table 2 are the results of the analysis for the quality of the working life of nurses.

Table 2 shows that the mean (mean) total quality of nursing work life (145.83) is below the average mean value of 150 . Likewise for the sub-variable value of the quality of the working life of nurses, all are below the standard mean value except for subvariable 
Irman Somantri : Quality of Nurse Work Life In Pangandaran Health Center

support services where the mean value (19.31) is above the standard mean value (18).

To see the relationship between the characteristics of officers and the quality of work life, because the results of the normality test obtained data were not normally distributed, then all analyzes used nonparametric analysis. The results can be seen in table 3 as follows.

Based on the data in table 3 , it can be seen that female respondents have a greater quality of work life compared to men, while for the education aspect it is seen that nurses who have a bachelor's degree and complete the professional profession program have a higher quality of work life compared to other levels of education. For the number of members in the team, it was felt that with a total of 4 members, this would provide more prosperity with a higher value compared to the larger number of team members, as well as for income, where an income of $>2.5$ million per month would provide quality value higher working life compared to those whose income is $<2.5$ million per month.

In the table also can be seen that gender and age do not have a relationship with the quality of work life ( $p$ value $>0.005$ ), while the level of education, the number of teams and salaries of the quality of work life of nurses in Puskesmas Pangandaran ( $\mathrm{p}$ value $<$ $0.001)$.

\section{Discussion}

The quality of the working life of the nurse is a reflection of the satisfaction of the nurse which has implications for several dimensions of life of the nurse itself, among the lives at home, the work environment, working conditions and the perception of the nurse about his work.

The quality of work life of nurses and other employees in Pangandaran Health Center is below the midpoint value (mean) which means that nurses and employees at Pangandaran Health Center have not felt well-being in their work, except in the support service aspect which has a value above the midpoint which means this aspect health (especially nursing) already feels a feeling of satisfaction and prosperity in getting support from other teams/officers in Pangandaran Health Center.

The motivation theory of Herzberg, the dimensions of the quality of work life is one of the factors maintaining the work motivation, which means that the quality of work life can be one of the factors of dissatisfaction for nurses, when the quality of work life is low, dissatisfaction will occur and the effect on low work motivation and vice versa (Marquis \& Houston, 2008).

The work context dimension is the process of setting the work of nurses and exploring the impact of the work environment on the system (Brooks \& Anderson, 2005) where in this study is included in the aspect of work environment, work condition and Relation with Managers which contains how nurses adapt to the environment, cooperation with the environment, comfort of work and policy (work envirionment) also analyzed how perceptions of workload, the effect of work on family, energy, division of work time and also the income earned (Work Conditions) and how nurses relate to the head of the Puskesmas (Relation with Managers) (Sirin \& Sokmen, 2015). Based on the results of the study obtained has a lower value than the theoretical midpoint which means that nurses and health workers have not felt welfare in accordance with the aspects mentioned above.

The aspect of support service based on the results of the study has a higher value than the middle value. This support service aspect contains the support system from the existing staff at the Puskesmas, the ease of obtaining and using facilities and infrastructure as well as assistance to provide maximum nursing care from other staff (Sirin \& Sokmen, 2015). In accordance with the results means that nurses and health workers in Puskesmas Pangandaran have felt good team work function in carrying out activities, for example cooperation in handling patients, division of tasks among officers and feeling of assistance from other staff when nurses carry out pickets at the Puskesmas.

Support Sevices aspect is part of work design where in this dimension describes the composition of the work done is actually done by the nurse (Luthans, 2011). 
Irman Somantri : Quality of Nurse Work Life In Pangandaran Health Center

Herzberg stated that the dimension of quality of work life is one of the factors maintaining the motivation of work, which means that the quality of work life can be one of the factors of dissatisfaction for nurses, when there is a low quality of work life, dissatisfaction will occur and affect low work motivation. (Marquis \& Houston, 2008).

Balanced compensation and a feeling of comfort while working are the most important things in improving employee welfare (Inda, 2013), as well as what is found in the relationship analysis above, it can be seen that the higher the income of the respondent it will relate to the welfare of the respondent with the direction of the relationship positive, which means that the higher the adequate income (with an average of 198.67) will give a feeling of satisfaction and prosperity for nurses and officers in the Pangandaran Health Center.

Even the level of education and the number of teams can also influence the quality of work life of nurses/officers where in the results it can be seen that when the education level of nurses has reached the level of higher education, the welfare of health workers is getting better, but the number of teams involved shows that the number of team members 4 people have a better impact on the quality of the worker's life.

This study has limitations, including the nursing work quality of life instruments in the literature review using more resources from Brooks and Anderson (2005) and until now no improvement has been found on the instrument, to overcome this, researchers try to adapt the theory from Brooks and Anderson (2005) with the theory of Sirin and Sokmen (2015) where before the instrument is used, the researcher tests the validity constructively to ensure that the instrument can be used.

\section{Conclusion}

Based on the results of the study, it can be concluded several things as follows;

Means of quality of work life of nurses in Pangandaran Health Center is below the midpoint value (average) which means that nurses in Pangandaran Health Center have not felt well-being in their work, except in the aspect of support service which has a value above the midpoint which means that this aspect of the nurse feel satisfied and prosperous in getting support from other teams/officers in Pangandaran Health Center. Subsequent analysis found that gender and age do not have a relationship with the quality of work life, while the level of education, the number of teams and salaries of the quality of work life of nurses in Pangandaran Health Center.

\section{References}

Brooks, B.A., \& Anderson, M.A. (2005). Defining quality of nursing work life. Nurs Econ, 319-326.

Dirjen Bina Upaya Kesehatan Kemenkes RI dan KARS. (2011). Standar akreditasi rumah sakit. Jakarta: Kementrian Kesehatan Republik Indonesia.

Inda, S.S. (2013). Quality of work life: $A$ comprehension study. Toronto: Canadian Academic Publishing.

Indeks Kesehatan. (2015). Available at pusdalisbang: http://pusdalisbang.jabarprov. go.id/pusdalisbang/indikatormakro-31.html indeks kesehatan.

Kotler, P., \& Keller, K.L. (2012). Marketing management. Boston: Prentice Hall.

Lembaran Negara Republik Indonesia. (2014). Undang-undang Nomor 75 tahun 2014.

Lembaran Negara Republik Indonesia. (2014). Undang-undang Republik Indonesia Nomor 38 tahun 2014 tentang Keperawatan.

Luthans, F. (2011). Organizational behaviour ( $7^{\text {th }}$ Ed.). New York: Mc. Graw Hill International.

Marquis, \& Houston. (2008). Leadership roles and management function in nursing. Philadelphia: Lippincot.

Nawawi, H. (2001). Manajemen sumber 
Irman Somantri : Quality of Nurse Work Life In Pangandaran Health Center

daya manusia untuk bisnis dan kompetitif. Yogyakarta: Gadjah mada University Press.

Nursalam. (2012). Manajemen keperawatan: Aplikasi dalam praktik keperawatan profesional. Jakarta: Salemba Medika.
Sirin, M., \& Sokmen, S.M. (2015). Quality of nursing work life scale: The psychometric evaluation of the Turkish version. International Journal of Caring Sciences, 543-554. 